\title{
ANALISIS FAKTOR-FAKOR YANG MEMPENGARUHI PREFERENSI MENABUNG NASABAH DI BPRS AMANAH UMMAH
}

\author{
Imam Mu'aziz \\ Ikhwan Hamdani \\ Ahmad Mulyadi Kosim \\ Fakultas Agama Islam Universitas Ibn Khaldun Bogor, Jawa Barat, Indonesia
}

\begin{abstract}
Penelitian ini bertujuan untuk mengetahui faktor-fakor yang mempengaruhi preferensi menabung nasabah menabung di BPRS Amanah Ummah, dan faktor apa yang paling dominan. Penelitian in bertujuan 1) Menganalisis faktor-faktor yang mempengaruhi preferensi menabung nasabah di BPRS Amanah. 2) menganalisis faktor yang dominan dalam mempengaruhi preferensi menabung nasabah di BPRS Amanah Ummah. Analisis dilakukan dengan analisis deskriptif dan analisis faktor. Penelitian ini dilakukan dari bulan Juli 2017 sampai dengan Oktober 2017. Sebanyak 100 nasabah yang diambil sebagai responden dengan teknik pengambilan purposive sampling. Jumlah variabel yang diteliti adalah 32 variabel. Data yang diolah dengan menggunakan analisis faktor sebanyak 26 variabel yang bisa dianalisis lebih lanjut. 6 variabel dikeluarkan karena tidak valid dalam pengujian validitas. Data yang diperoleh dari responden diolah dengan menggunakan SPSS 16.0 For Windows. Sebanyak lima faktor tebentuk dalam analisis ini, dari pengelompokan 26 variabel yang valid memenuhi syarat pada analisis faktor. Fakor pertama yang mempengaruhi preferensi menabung nasabah di BPRS Amanah Ummah faktor pelayanan prima (service excelence), faktor kedua faktor keuntungan, faktor ketiga faktor lokasi. faktor keempat faktor sosial dan kondisi bank, dan faktor kelima faktor fasilitas. Dari keseluruhan faktor tersebut faktor pelayanan prima merupakan faktor yang paling dominan.
\end{abstract}

Kata Kunci : BPRS, Preferensi, Analisis Faktor

\section{Introduction}

Keberadaan bank pembiayaan rakyat syariah sangat penting bagi pertumbuhan ekonomi dan diharapkan dapat menggerakkan sektor riil. Bank pembiayaan rakyat syariah memiliki sistem operasional yang berbeda dengan bank perkreditaan rakyat konvensional. Bank pembiayaan rakyat syariah memberikan layanan bebas bunga kepada para nasabahnya. Dalam sistem operasional bank syariah, pembayaran dan penarikan bunga dilarang dalam semua bentuk transaksi. Baik bunga yang diperoleh dari pembiayaan nasabah atau bunga yang dibayar kepada penyimpan dana di bank pembiayaan rakyat syariah.

Hingga sekarang perkembangan bank pembiayaan rakyat syariah di Indonesia saat ini menunjukkan tanda-tanda yang baik walaupun jika dibandingkan dengan bank konvensional pertumbuhan bank pembiayaan rakyat syariah masih jauh untuk mencapai kesetaraan. Namun, hal ini berarti perwujudan dari permintaan masyarakat yang membutuhkan suatu sistem perbankan yang alternatif yang menyediakan produk yang sehat, terpercaya, dan memenuhi prinsip syariah yang mengutamakan prinsip keadilan. 
Tabel 1: Kegiatan usaha Bank Pembiayaan Rakyat Syariah

\begin{tabular}{|l|c|c|c|}
\hline \multirow{2}{*}{ Indikator } & Tahun 2015 & Tahun 2016 & Tahun 2017 \\
\cline { 2 - 4 } & $\begin{array}{c}\text { Jumlah } \\
\text { ( Miliar Rupiah) }\end{array}$ & $\begin{array}{c}\text { Jumlah } \\
\text { ( Miliar Rupiah) }\end{array}$ & $\begin{array}{c}\text { Jumlah } \\
\text { ( Miliar Rupiah) }\end{array}$ \\
\hline Pembiayaan & 5765,17 & 6662,56 & 7399,52 \\
\hline Dana pihak ketiga & 4801,89 & 5823,96 & 6113,52 \\
\hline Total aset & 6573,33 & 7739,27 & 9654,41 \\
\hline
\end{tabular}

Sumber : Otoritas Jasa Keuangan, statistika perbankan syariah, Mei 2017 (Diolah)

Dari tabel di atas dapat diketahui cukup signifikannya Dana Pihak Ketiga (DPK) yang berhasil dihimpun oleh bank pembiayaan rakyat syariah mengindikasikan bahwa kepercayaan masyarakat untuk menyimpan dana di bank pembiayaan rakyat syariah sudah cukup baik. Ini tentu akan menjadi modal sosial bagi bank pembiayaan rakyat syariah untuk meningkatkan kinerja dan mutu pelayanan. Dana DPK adalah salah satu unsur pembentukan pendapatan bank pembiayaan rakyat syariah karena dari DPK akan disalurkan dalam bentuk pembiayaan. Selanjutnya pembiayaan yang disalurkan akan diperoleh tingkat pengembaian margin dari bagi hasil. Oleh karena itu optimalisasi DPK menjadi sangat penting untuk kelancaran usaha bank pembiayaan rakyat syariah.

Salah satu diantara beberapa bank pembiayaan syariah adalah Bank Pembiayaan Rakyat Syariah (BPRS) Amanah Ummah. Perjalanan Pada awal Februari 1991 dibentuk tim untuk menyusun proposal pendirian Bank Syariah, Seiring berjalannya waktu pertumbuhan dan perkembangan BPRS Amanah Ummah menunjukkan peningkatan yang signifikan. Hal ini terlihat dari peningkatan jumlah nasabah dan penambahan kantor yang kini telah memiliki jaringan kantor yang tersebar di wilayah Bogor dan Sukabumi.

Memerhatikan fungsi pokok lembaga pembiayaan syariah sebagai lembaga intermediasi dana serta menyadari betapa vitalnya keberadaan dana pihak ketiga bagi kelangsungan usaha bank pembiayaan rakyat syariah maka kegiatan penghimpunan DPK menjadi bagian kegiatan operasional yang selalu mendapat perhatian serius dari setiap manajemen bank pembiayaan rakya syariah. Sehingga masyarakat mau menyimpan dananya ke bank pembiayaan rakyat syariah dalam bentuk tabungan ataupun deposito.

Melihat latar belakang bahwa DPK merupakan faktor terpenting untuk peningkatan jalannya usaha BPRS Amanah Ummah, maka penulis menganggap begitu penting untuk mengetahui faktor-faktor apa saja yang mempengaruhi preferensi nasabah untuk menabung di BPRS Amanah Ummah. Sehingga dapat dirumuskan masalah penelitian, yaitu untuk mengetahui pertama faktor-faktor apa saja yang mempengaruhi preferensi menabung nasabah di BPRS Amanah Ummah, dan kedua faktor- faktor apa saja yang lebih dominan mempengaruhi preferensi menabung nasabah di Amanah Ummah. 


\section{Literature Review}

\subsection{Strategi Pemasaran}

Strategi pemasaran adalah suatu rencana yang didesain untuk mempengaruhi pertukaran dalam mencapai tujuan organisasi. Biasanya strategi pemasaran diarahkan untuk meningkatkan kemungkinan atau frekuensi perilaku konsumen, seperti peningkatan kunjungan pada suatu toko tertentu. Hal ini dapat dicapai dengan mengembangkan dan menyajikan bauran pemasaran (Marketing Mix) yang diarahkan pada pasar sasaran yang terpilih.

Suatu bauran pemasaran terdiri dari komponen lokasi atau tempat, produk, harga, komunikasi (promosi), kepuasan, dan pelayanan yang diberikan kepada konsumen dari pasar sasaran.

1) Lokasi, Dalam bisnis jasa bank, penentuan lokasi dimana bank akan beroperasi merupakan salah satu faktor yang penting. Dalam persaingan yang ketat penentuan lokasi mempunyai pengaruh cukup signifikan dalam aktivitas menghimpun dana masyarakat serta menyalurkan pembiayaan kembali kepada masyarakat. Sebab dengan penentuan lokasi yang tepat maka target pencapaian bank akan dapat diraih.

2) Produk, Suatu produk adalah apa saja yang dibutuhkan dan diinginkan seseorang konsumen, untuk memenuhi kebutuhan yang dipersepsikan.

3) Komunikasi (Promosi), kegiatan untuk memperkenalkan produk dan jasa yang dimiliki bank baik langsung maupun tidak langsung.

4) Harga, pada setiap produk atau jasa yang ditawarkan, bagian pemasaran dapat menentukan harga pokok dan harga jual suatu produk.

5) Kepuasan, keyakinan konsumen tentang apa yang telah diterimanya apabila ia membeli atau mengkonsumsi suatu produk baik itu berupa barang atau jasa.

\subsection{Perilaku Konsumen}

The american marketing association mendefinisikan perilaku konsumen adalah interaksi dinamis antar afeksi dan kognisi, perilaku, dan lingkungannya dimana manusia melakukan pertukaran dalam hidup mereka.

Perilaku konsumen bersifat dinamis, artinya bahwa perilaku seorang konsumen, grup konsumen, ataupun masyarakat luas selalu berubah dan bergerak sepanjang waktu. Dalam hal ini studi perilaku konsumen, salah satu implikasinya adalah bahwa generalisasi perilaku konsumen biasanya terbatas pada jangka waktu tertentu, produk, dan individu tertentu. (Nugroho J. Setiad, 2013)

Keputusan pembelian dari pembeli sangat dipengaruhi oleh faktor kebudayaan (budaya), sosial, pribadi, dan psikologi dari pembeli.( Philip Kotler dan Kavin Lane Keller, 2019: 166)

1) Faktor kebudayaan ( budaya)

Faktor budaya berpengaruh paling besar terhadap perilaku konsumen. Kebudayaan merupakan penentu yang paling mendasar pada keinginan dan perilaku manusia. Setiap budaya terdiri dari beberapa sub budaya (sub culture) yang lebih kecil memberikan identifikasi dan sosialisasi yang lebih spesifik untuk anggota mereka. Sub budaya meliputi 
kebangsaan, agama, kelompok ras, dan wilayah geografis. Ketika sub budaya tumbuh besar dan cukup kaya, perusahaan sering merancang program pemasaran khusus untuk melayani mereka.

2) Faktor sosial

Perilaku konsumen juga dipengaruhi oleh faktor-faktor sosial seperti kelompok referensi, keluarga, serta peranan dan status sosial. Kelompok Referensi (reference group) seseorang adalah kelompok yang mempunyai pengaruh langsung (tatap muka) atau tidak langsung terhadap sikap dan perilaku orang tersebut. Keluarga adalah organisasi pembelian konsumen yang paling penting dalam masyarakat dan anggota keluarga mempresentasikan kelompok referensi utama yang paling berpengaruh. Peran dan status orang berpartisipasi dalam banyak kelompok-keluarga, klub, organisasi. Kelompok sering mejadi sumber informasi penting dan membantu mendefinisikan norma perilaku. Kita dapat mendefinisikan posisi seseorang dalam tiap kelompok dimana ia menjadi anggota berdasarkan peran dan status. Peran (role) terdiri dari kegiatan yang diharapkan dapat dilakukan seseorang. Setiap peran mengandung status.

3) Faktor Pribadi

Faktor pribadi meliputi usia dan tahapan dalam siklus hidup pembeli; pekerjaan dan keadaan ekonomi, kepribadian dan konsep diri, serta gaya hidup dan nilai karena banyak dari karakteristik ini yang mempunyai dampak yang sangat langsung terhadap perilaku konsumen. Konsumen juga dibentuk oleh siklus hidup keluarga adan jumlah, usia, serta jenis kelamin orang dalam rumah tangga pada satu waktu tertentu, yaitu suami-istri dan dua anak menduduki persentasi total rumah tangga yang jauh lebih kecil dari sebelumnya. Selain itu, tahap siklus hidup psikologis bisa menjadi masalah. Orang dewasa mengalami perjalanan atau transformasi tentu sepanjang hidupnya. tetapi perilaku yang diperlihatkan seseorang ketika mereka melalui perjalanan ini, misalnya menjadi orang tua, tidak selalu tetap dan berubah sepanjang waktu. Pekerjaan dan keadaan ekonomi, Pekerjaan seseorang berpengaruh terhadap kebutuhan pada barang dan jasa, pemasar berusaha mengidentifikasi kelompok pekerjaan yang mempunyai minat di atas rata-rata terhadap produk dan jasa mereka dan bahkan mengantarkan produk khusus untuk kelompok pekerjaan tertentu. Kepribadian dan konsep diri, setiap orang mempunyai karakteristik pribadi yang mempengaruhi perilaku pembeliannya. Yang dimaksud dengan kepribadian (personality) adalah sekumpulan sifat psikologi manusia yang menyebabkan respons yang relatif konsisten dan tahan lama terhadap rangsangan lingkungan (termasuk perilaku pembelian). Gaya hidup (lifestyle) adalah pola hidup seseorang di dunia yang tercermin dalam kegiatan minat, dan pendapat. Gaya hidup memotret interaksi seseorang secara utuh dengan lingk ungan.

4) Faktor Psikologi

Pilihan pembelian seseorang juga dipengaruhi oleh faktor psikologi yang utama, yaitu motivasi, persepsi, proses belajar, serta kepercayaan dan sikap. Motivasi ialah alasanalasan untuk berperilaku. Motif merupakan kerangka yang mencerminkan pengaruh dari dalam diri yang mendorong perilaku dan memberi arah kepada respons yang timbul. Persepsi adalah proses seorang individu memilih, mengorganisasi, dan mengintepretasikan 
masukan-masukan untuk menciptakan gambaran bermakna. Pembelajaran meliputi perubahan perilaku seseorang yang timbul dari pengalaman. Keyakinan adalah gambaran pemikiran yang dianut seseorang tentang suatu hal. Adapun sikap adalah evaluasi, perasaan emosional, dan kecenderungan tindakan yang menguntungkan atau tidak menguntungkan dan bertahan lama dari seseorang terhadap suatu objek atau gagasan.

\subsection{Preferensi}

Preferensi adalah langkah pertama untuk menjelaskan alasan seseorang lebih suka suatu jenis produk dari jenis produk yang lainnya.(Philip Kotler, 2009:200). Preferensi mempunyai makna pilihan atau memilih. Istilah preferensi untuk mengganti kata preference dengan arti yang sama dengan minat terhadap sesuatu. Preferensi merupakan suatu sifat atau keinginan untuk memilih. Menurut Indiarto preferensi konsumen didefiniskan sebagai selera subjektif dari suatu individu, yang diukur dengan utilitas, dari bundel berbagai barang. Konsumen dipersilahkan untuk melakukan rangking terhadap bundel barang yang produsen tawarkan kepada konsumen. Yang perlu diperhatikan preferensi bersifat independen terhadap pendapatan dan harga.

\section{$2.4 \quad$ BPRS}

Menurut Undang- Undang perbankan Nomor 10 tahun 1998 yang dimaksud dengan bank adalah badan usaha yang menghimpun dana dari masyarakat dalam bentuk simpanan dan menyalurkannya ke masyarakat dalam bentuk kredit dan atau bentuk lainnya dalam meningkatkan taraf hidup rakyat banyak. Bank menghimpun dana masyarakat kemudian menyalurkan dananya ke masyarakat dengan tujuan untuk mendorong taraf hidup rakyat banyak. Menurut UU No. 21 Tahun 2008 tentang perbankan syariah Bank Pembiayaan Rakyat Syariah adalah Bank Syariah yang dalam kegiatannya tidak memberikan jasa dalam lalu lintas pembayaran. Jadi pengertian BPRS pada dasarnya sama dengan bank syariah namun yang membedakan adalah pada kegiatan BPRS jumlah jasa yang dilakukan BPRS jauh lebih sempit.

\section{Metode Penelitian}

\subsection{Lokasi Penelitian}

Penelitian ini dilakukan di BPRS Amanah Ummah yang berlokasi di Jl. Raya Leuwiliang. Alasan penulis memilih BPRS Amanah Ummah sebagai penelitian karena BPRS Amanah Ummah merupakan Kantor Pusat yang berlokasi di area heterogen, yaitu mencakup wilayah perkantoran, pertokoan, pasar, dan pemukiman.

\subsection{Populasi dan Sample}

Dalam penelitian ini yang dijadikan populasi adalah jumlah nasabah yang mempunyai rekening tabungan di BPRS amanah ummah. Teknik pengambilan sampel yang digunakan dalam penelitian ini adalah Non-Probabilitas artinya setiap anggota populasi tidak memiliki peluang atau kesempatan yang sama sebagai sempel, dan cara pengambilan sampel yang digunakan adalah cara dipermudah convenience sampling. Manfaat dari cara ini, hasil 
penelitian dapat menunjukkan bukti-bukti yang cukup berlimpah. Pengambilan sampel dengan cara convenience sampling adalah sampel diambil berdasarkan ketersediaan elemen dan kemudahan untuk mendapatkannya. Dengan kata lain sampel diambil atau terpilih karena ada ditempat dan waktu yang tepat. (Suryani dan Hendryadi, 2015:194)

Besarnya jumlah sampel minimal yang dibutuhkan dalam penelitian ini ditentukan dengan rumus formula solvin yaitu:

$$
n=\frac{N}{1+N d^{2}}
$$

Dimana :

$\mathrm{n} \quad=\quad$ Ukuran sampel

$\mathrm{N}=$ Ukuran Populasi $=17.175$ ( merupakan jumlah nasbah BPRS

Amanah Ummah yang mempunyai rekening tabungan hingga

September 2017)

$\mathrm{d}=$ Persen kelonggaran ketidakpastian karana kesalahan pengambilan sampel yang dapat ditolerir $=10 \%$

$n=\frac{17.175}{1+17.175(0.1)^{2}}$

$n=\frac{17 \cdot 175}{1+17 \cdot 175(0,01)}$

$n=\frac{17.175}{1+171,75}$

$n=\frac{17.175}{172,75}=99,42$ dibulatkan menjadi 100

Jadi, besarnya sampel yang digunakan dalam penelitian ini adalah sebanyak 100 orang responden yang dianggap sudah mewakili.

\subsection{Teknik Pengumpulan Data}

Dalam penelitian ini penulis mengumpulkan data yang digunakan dengan menggunakan metode pengumpulan data sebagai berikut :

1. Studi Pustaka

Melalui studi ini didapat konsep, teori, dan definisi- definisi yang penulis gunakan sebagai landasan berfikir dan analisa dalam proses penulisan.

2. Studi lapangan

Studi lapangan yang digunakan untuk mendapatkan data primer dalam penelitian ini bersumber dari angket atau kuesioner.

\subsection{Metode Analisis Data}

Teknik analisis data yang digunakan dalam penelitian ini adalah analisis dsekriptif dan analisis faktor. Teknik analisis faktor digunakan untuk menjawab permasalahan yang berkaitan dengan faktor manakah yang paling dominan yang mempengaruhi preferensi nasabah, dan mengetahui sejauh mana faktor-faktor yang diduga peneliti pada awal penelitian mempengaruhi preferensi menabung nasabah, khususnya nasabah BPRS Amanah Ummah. 


\section{Hasil Penelitian dan Pembahasan}

Untuk mendapatkan data primer dalam penelitian ini dilakukan wawancara kepada responden berupa kuesioner, responden adalah para nasabah yang menabung di BPRS Amanah Ummah. Sebelum dilakukan wawancara kepada 100 orang responden, terlebih dahulu dilakukan uji coba kepada 30 responden dengan mengajukan 32 pernyataan untuk melakukan uji validitas dan reliabilitas dari semua pernyataan tersebut. Dari hasil uji coba untuk menentukan valid atau tidaknya pernyataan, maka untuk pernyataan yang tidak valid akan dikeluarkan dari instrumen. Sehingga akan terbentuk semua pernyataan valid yang kemudian akan di lanjutkan dengan menguji pernyataan valid kepada 100 orang responden. Untuk menguji Validitas menggunakan program SPSS dengan melihat Correlated Item-Total Correlation.

Dari hasil uji coba menggunakan 30 kuesioner dengan 32 pernyataan yang diajukan kepada responden. Setelah memperoleh $\mathrm{r}$ hitung yang dilihat pada nilai Correlated Item-Total Correlation, selanjutnya untuk dapat diputuskan instrumen tersebut valid atau tidak, nilai tersebut dibandingkan dengan nilai $\mathrm{r}$ tabel. Dengan sempel sebanyak 30 responden maka dapat diketahui nilai $\mathrm{r}$ tabel dengan signifikan 5\% diperoleh 0,361 . jika nilai korelasi $\mathrm{r}$ hitung $<\mathrm{r}$ tabel maka dapat dinyatakan bahwa variabel tersebut tidak valid dan jika nilai korelasi $\mathrm{r}$ hitung>r tabel maka dapat dinyatakan variabel tersebut valid dan dapat diujikan kepada 100 responden. Dari 32 butir pernyataan terdapat 6 butir pernyataan yang korelasinya lebih kecil dari $\mathrm{r}$ tabel yaitu variabel 3 dengan nilai $0,118<0,361$, variabel 4 dengan nilai $0,252<0,361$, variabel 6 dengan nilai $0,306<0,361$, variabel 18 dengan nilai $0,246<0,361$, variabel 27 dengan nilai $0,291<0,361$, variabel 28 dengan nilai $0,338<0,361$, itu artinya butir pernyataan tersebut tidak valid dan harus dikeluarkan dari variabel, sehingga menghasilkan 26 pernyataan yang tersisa, kemudia melakukan uji kembali untuk mencari variabel yang valid yang akan digunakan untuk analis is berikutnya.

Untuk pengujian validitas digunakan 100 kuesioner dengan 26 butir pernyataan yang diajukan kepada responden, dan $\mathrm{r}$ tabel signifikan 5\%=0,1946 (tabel $\mathrm{r}$ terlampir) untuk mengetahui apakah butir-butir pernyataan dalam kuesioner tersebut valid. Dari hasil pengujian 100 kuisioner menghasilkan bahwa semua butir pernyataan valid nilai $r$ hitung>dari $r$ tabel (0.195), dan dari 26 pernyataan tersebut akan dianalisis lebih lanjut.

\subsection{Karaketeristik Responden}

1) Jenis kelamin

Tabel 2: Jenis Kelamin Responden

\begin{tabular}{|c|c|c|c|c|c|}
\hline & & Frequency & Percent & Valid Percent & $\begin{array}{c}\text { Cumulative } \\
\text { Percent }\end{array}$ \\
\hline \multirow[t]{3}{*}{ Valid } & Laki-laki & 55 & 55.0 & 55.0 & 55.0 \\
\hline & Perempuan & 45 & 45.0 & 45.0 & 100.0 \\
\hline & Total & 100 & 100.0 & 100.0 & \\
\hline
\end{tabular}

Sumber : Hasil Output SPSS 
Dari tabel jenis kelamin responden dapat dilihat bahwa terdapat 55 reponden atau 55\% responden berjenis kelamin laki-laki. Sedangkan selebihnya sebanyak 45 reponden atau $45 \%$ responden berjenis kelamin perempuan.

2) Usia

Tabel 3: Usia Responden

\begin{tabular}{|c|c|c|c|c|c|}
\hline & & Frequency & Percent & Valid Percent & $\begin{array}{c}\text { Cumulative } \\
\text { Percent }\end{array}$ \\
\hline \multirow[t]{7}{*}{ Valid } & 10-19 tahun & 6 & 6.0 & 6.0 & 6.0 \\
\hline & 20-29 tahun & 29 & 29.0 & 29.0 & 35.0 \\
\hline & 30-39 tahun & 30 & 30.0 & 30.0 & 65.0 \\
\hline & 40-49 tahun & 16 & 16.0 & 16.0 & 81.0 \\
\hline & 50-59 tahun & 15 & 15.0 & 15.0 & 96.0 \\
\hline & $>60$ tahun & 4 & 4.0 & 4.0 & 100.0 \\
\hline & Total & 100 & 100.0 & 100.0 & \\
\hline
\end{tabular}

Sumber : Hasil Output SPSS

Dari tabel usia responden dapat dilihat bahwa terdapat 6 reponden atau 6\% responden berusia antara 10-19 tahun, sebanyak 29 responden atau $29 \%$ responden berusia antara 20-29 tahun, sebanyak 30 responden atau 30\% responden berusia antara 30-39 tahun, sebanyak 16 reponden atau $16 \%$ reponden berusia antara 40-49 tahun, sebanyak 15 responden atau $15 \%$ reponden berusia antara 50-59 tahun. Sedangkan selebihnya sebanyak 4 reponden atau $4 \%$ berusia lebih dari 60 tahun.

3) Status

Tabel 4: Status Pernikahan Responden

\begin{tabular}{|c|c|c|c|c|c|}
\hline & & Frequency & Percent & $\begin{array}{c}\text { Valid } \\
\text { Percent }\end{array}$ & $\begin{array}{c}\text { Cumulative } \\
\text { Percent }\end{array}$ \\
\hline \multirow[t]{3}{*}{ Valid } & Menikah & 80 & 80.0 & 80.0 & 80.0 \\
\hline & Belum Menikah & 20 & 20.0 & 20.0 & 100.0 \\
\hline & Total & 100 & 100.0 & 100.0 & \\
\hline
\end{tabular}

Sumber : Hasil Output SPSS

Dari tabel status responden dapat dilihat bahwa terdapat 80 reponden atau $80 \%$ responden berstatus menikah. Sedangkan selebihnya sebanyak 20 reponden atau $20 \%$ responden belum menikah.

4) Asal daerah

Tabel 5: Alamat Responden

\begin{tabular}{|c|c|c|c|c|c|}
\hline & & Frequency & Percent & Valid Percent & $\begin{array}{c}\text { Cumulative } \\
\text { Percent }\end{array}$ \\
\hline \multirow[t]{4}{*}{ Valid } & Leuwiliang & 56 & 56.0 & 56.0 & $\overline{56.0}$ \\
\hline & Ciampea & 4 & 4.0 & 4.0 & 60.0 \\
\hline & Cibungbulang & 11 & 11.0 & 11.0 & 71.0 \\
\hline & Dramaga & 3 & 3.0 & 3.0 & 74.0 \\
\hline
\end{tabular}




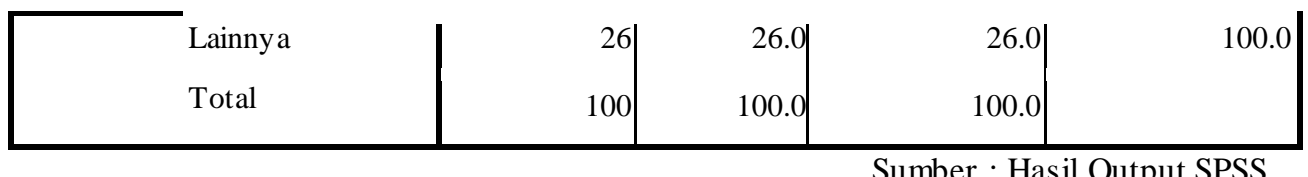

Sumber : Hasil Output SPSS

Dari tabel asal daerah responden dapat dilihat bahwa terdapat 56 reponden atau $56 \%$ responden berasal dari daerah Leuwiliang, sebanyak 4 responden atau $4 \%$ responden berasal dari daerah Ciampea, sebanyak 11 responden atau $11 \%$ responden berasal dari daerah Cibungbulang, sebanyak 3 reponden atau $3 \%$ reponden berasal dari daerah Dramaga. Sedangkan selebihnya sebanyak 26 reponden atau $26 \%$ berasal dari daerah lainnya.

5) Agama

Tabel 6: Agama Responden

\begin{tabular}{|c|c|c|c|c|c|}
\hline & & Frequency & Percent & Valid Percent & $\begin{array}{c}\text { Cumulative } \\
\text { Percent }\end{array}$ \\
\hline \multirow[t]{4}{*}{ Valid } & Islam & 93 & 93.0 & 93.0 & 93.0 \\
\hline & Kristen & 2 & 2.0 & 2.0 & 95.0 \\
\hline & Budha & 5 & 5.0 & 5.0 & 100.0 \\
\hline & Total & 100 & 100.0 & 100.0 & \\
\hline
\end{tabular}

Sumber : hasil Output SPSS

Dari tabel agama responden dapat dilihat bahwa terdapat 93 reponden atau 93\% responden beragama Islam, sebanyak 2 responden atau $2 \%$ responden beragama Kristen. Sedangkan selebihnya sebanyak 5 reponden atau 5\% responden beragama Budha.

6) Pendidikan

Tabel 7: Pendidikan Terakhir Responden

\begin{tabular}{|ll|r|r|r|r|}
\hline & & & & \multicolumn{2}{c|}{$\begin{array}{c}\text { Cumulative } \\
\text { Percent }\end{array}$} \\
\hline Valid & Frequency & Percent & Valid Percent & 15.0 \\
& SD/MI Sederajat & 15 & 15.0 & 15.0 & 43.0 \\
& 28 & 28.0 & 28.0 & 82.0 \\
SMP/MTS Sederajat & 39 & 39.0 & 39.0 & 86.0 \\
& & 4 & 4.0 & 4.0 & 99.0 \\
Diploma & 13 & 13.0 & 13.0 & 100.0 \\
S1 & 1 & 1.0 & 1.0 & \\
S2 & 100 & 100.0 & 100.0 & \\
Total & & & \\
\end{tabular}

Sumber : Hasil Output SPSS

Dari tabel pendidikan terakhir responden dapat dilihat bahwa terdapat 15 reponden atau $15 \%$ responden pendidikan terakhirnya adalah SD/ MI, sebanyak 28 responden atau $28 \%$ responden pendidikan terakhirnya adalah SMP/MTS, sebanyak 39 responden atau $39 \%$ responden pendidikan terakhirnya adalah SMA/SMK/MA, sebanyak 4 responden atau $4 \%$ responden pendidikan terakhirnya adalah Diploma, sebanyak 13 responden atau $13 \%$ responden pendidikan terakhirnya adalah $\mathrm{S} 1$. Sedangkan selebihnya sebanyak 1 reponden atau $1 \%$ responden pendidikan terkahirnya adalah $\mathrm{S} 2$. 
7) Pekerjaan

Tabel 8: Pekerjaan Responden

\begin{tabular}{|l|r|r|r|r|}
\hline & Frequency & Percent & Valid Percent & $\begin{array}{c}\text { Cumulative } \\
\text { Percent }\end{array}$ \\
\hline Valid & 3 & 3.0 & 3.0 & 3.0 \\
& 21 & 21.0 & 21.0 & 24.0 \\
Pegawai Negeri & 55 & 55.0 & 55.0 & 79.0 \\
Pedagang & 2 & 2.0 & 2.0 & 81.0 \\
Buruh/ Tani & 9 & 9.0 & 9.0 & 90.0 \\
Wiraswasta & 5 & 5.0 & 5.0 & 95.0 \\
Ibu Rumah Tangga & 5 & 5.0 & 5.0 & 100.0 \\
Pelajar/ Mahasiswa & 100 & 100.0 & 100.0 & \\
Total & & & \\
\hline
\end{tabular}

Sumber : Hasil Output SPSS

Dari tabel pekerjaan responden dapat dilihat bahwa terdapat 3 reponden atau $3 \%$ responden bekerja sebagai Pegaawai negeri, sebanyak 21 responden atau $21 \%$ responden bekerja sebagai Pegawai Swasta, sebanyak 55 responden atau $55 \%$ responden bekerja sebagai pedagang, sebanyak 2 responden atau $2 \%$ responden bekerja sebagai Buruh/ Tani, sebanyak 9 responden atau $9 \%$ responden bekerja sebagai Wisaswasta, sebanyak 5 responden atau $5 \%$ responden bekerja sebagai Ibu rumah tangga. Sedangkan selebihnya sebanyak 5 reponden atau 5\% responden bekerja sebagai Pelajar/ Mahasiswa.

8) Pengeluaran perbulan

Tabel 9: Pengeluaran Responden Dalam Satu Bulan

\begin{tabular}{|c|c|c|c|c|c|}
\hline & & Frequency & Percent & $\begin{array}{c}\text { Valid } \\
\text { Percent }\end{array}$ & $\begin{array}{c}\text { Cumulative } \\
\text { Percent }\end{array}$ \\
\hline \multirow[t]{7}{*}{ Valid } & $<$ Rp. 500.000 & 8 & 8.0 & 8.0 & 8.0 \\
\hline & Rp.500.001-Rp. 1.500 .000 & 18 & 18.0 & 18.0 & 26.0 \\
\hline & Rp. 1.500.001-Rp. 2.500 .000 & 19 & 19.0 & 19.0 & 45.0 \\
\hline & Rp. 2.500.001-Rp. 3.500 .000 & 19 & 19.0 & 19.0 & 64.0 \\
\hline & Rp. 3.500.001-Rp. 4.500 .000 & 18 & 18.0 & 18.0 & 82.0 \\
\hline & > Rp. 4.500 .001 & 18 & 18.0 & 18.0 & 100.0 \\
\hline & Total & 100 & 100.0 & 100.0 & \\
\hline
\end{tabular}

Dari tabel pengeluaran perbulan responden dapat dilihat bahwa terdapat 8 reponden atau $8 \%$ responden selama satu bulan mengeluarkan biaya < Rp. 500.000 untuk segala keperluannya, sebanyak 18 reponden atau $18 \%$ responden selama satu bulan mengeluarkan biaya Rp. 500.001-Rp. 1.500 .000 untuk segala keperluannya, sebanyak 19 reponden atau 19 $\%$ responden selama satu bulan mengeluarkan biaya Rp. 1500.001-Rp. 2.500.000 untuk segala keperluannya, sebanyak 19 reponden atau $19 \%$ responden selama satu bulan mengeluarkan biaya Rp. 2.500.001-Rp. 3.500.000 untuk segala keperluannya, sebanyak 18 reponden atau $18 \%$ responden selama satu bulan mengeluarkan biaya Rp. 3.500.001-Rp. 4.500.000 untuk segala keperluannya. Sedangkan selebihnya sebanyak 18 reponden atau 18 
$\%$ responden selama satu bulan mengeluarkan biaya > Rp. 4.500 .000 untuk segala keperluannya.

9) Simpanan perbulan

Tabel 10: Simpanan Perbulan Responden

\begin{tabular}{|c|c|c|c|c|c|}
\hline & & Frequency & Percent & $\begin{array}{c}\text { Valid } \\
\text { Percent }\end{array}$ & $\begin{array}{c}\text { Cumulative } \\
\text { Percent }\end{array}$ \\
\hline \multirow[t]{7}{*}{ Valid } & $<$ Rp. 500.000 & 24 & 24.0 & 24.0 & 24.0 \\
\hline & Rp. 500.001-Rp. 1.500 .000 & 24 & 24.0 & 24.0 & 48.0 \\
\hline & Rp. 1.500.001-Rp. 2.500 .000 & 19 & 19.0 & 19.0 & 67.0 \\
\hline & Rp. 2.500.001-Rp. 2.500 .000 & 8 & 8.0 & 8.0 & 75.0 \\
\hline & Rp. 3.500.001-Rp. 4.500 .000 & 8 & 8.0 & 8.0 & 83.0 \\
\hline & > Rp. 4.500 .001 & 17 & 17.0 & 17.0 & 100.0 \\
\hline & Total & 100 & 100.0 & 100.0 & \\
\hline
\end{tabular}

Sumber : Hasil Output SPSS

Dari tabel simpanan perbulan responden dapat dilihat bahwa terdapat 24 reponden atau $24 \%$ responden selama satu bulan menyisihkan uangnya untuk disimpan < Rp. 500.000, sebanyak 24 reponden atau $24 \%$ responden selama satu bulan menyisihkan uangnya untuk disimpan Rp. 500.001-Rp. 1.500.000, sebanyak 19 reponden atau $19 \%$ responden selama satu bulan menyisihkan uangnya untuk disimpan Rp. 1.500.001-Rp. 2.500.000, sebanyak 8 reponden atau $8 \%$ responden selama satu bulan menyisihkan uangnya untuk disimpan $\mathrm{Rp}$. 2.500.001-Rp. 3.500.000, sebanyak 8 reponden atau $8 \%$ responden selama satu bulan menyisihkan uangnya untuk disimpan Rp. 3.500.001-Rp. 4.500.000. Sedangkan selebihnya sebanyak 17 reponden atau $17 \%$ responden selama satu bulan menyisihkan uangnya untuk disimpan > Rp. 4.500.000.

10) Jenis Tabungan

Tabel 11: Jenis tabungan yang digunakan Responden

\begin{tabular}{|c|c|c|c|c|c|}
\hline & & Frequency & Percent & $\begin{array}{c}\text { Valid } \\
\text { Percent }\end{array}$ & $\begin{array}{l}\text { Cumulative } \\
\text { Percent }\end{array}$ \\
\hline \multirow[t]{6}{*}{ Valid } & Tabungan Wadi'ah & 66 & 66.0 & 66.0 & 66.0 \\
\hline & Tabungan Mudharabah Haji & 1 & 1.0 & 1.0 & 67.0 \\
\hline & Deposito Mudharabah & 5 & 5.0 & 5.0 & 72.0 \\
\hline & Tabungan Pelajar & 4 & 4.0 & 4.0 & 76.0 \\
\hline & Tabungan Simpel IB & 24 & 24.0 & 24.0 & 100.0 \\
\hline & Total & 100 & 100.0 & 100.0 & \\
\hline
\end{tabular}

Dari tabel jenis tabungan yang digunakan responden dapat dilihat bahwa terdapat 66 reponden atau 66\% responden menggunakan jenis tabungan Wadi'ah, sebanyak 1 responden atau $1 \%$ responden menggunakan jenis tabungan mudharabah haji, sebanyak 5 responden atau $5 \%$ responden menggunakan jenis deposito mudharabah, sebanyak 4 reponden atau $4 \%$ reponden menggunakan jenis tabungan pelajar. Sedangkan selebihnya sebanyak 24 reponden atau $24 \%$ menggunakan jenis tabungan. 
11) Lama menjadi nasabah

Tabel 12: Lama Menjadi Nasabah BPRS Amanah Ummah

\begin{tabular}{|c|c|c|c|c|c|}
\hline & & Frequency & Percent & Valid Percent & $\begin{array}{c}\text { Cumulative } \\
\text { Percent }\end{array}$ \\
\hline \multirow[t]{5}{*}{ Valid } & $<1$ tahun & 12 & 12.0 & 12.0 & 12.0 \\
\hline & 1-2 tahun & 18 & 18.0 & 18.0 & 30.0 \\
\hline & 2-3 tahun & 16 & 16.0 & 16.0 & 46.0 \\
\hline & $>3$ tahun & 54 & 54.0 & 54.0 & 100.0 \\
\hline & Total & 100 & 100.0 & 100.0 & \\
\hline
\end{tabular}

Sumber : Hasil Output SPSS

Dari tabel lama menjadi nasabah BPRS Amanah Ummah dapat dilihat bahwa terdapat 12 reponden atau 12\% responden < 1 tahun menjadi nasabah BPRS Amanah Ummah, sebanyak 18 reponden atau 18\% responden 1-2 tahun menjadi nasabah BPRS Amanah Ummah, sebanyak 16 reponden atau 16\% responden 2-3 tahun menjadi nasabah BPRS Amanah Ummah. Sedangkan selebihnya sebanyak 54 reponden atau $54 \%$ responden > 3 tahun menjadi nasabah BPRS Amanah Ummah.

\subsection{Discussion}

Selanjutnya setelah pembahasan analisis uji validitas dan analisis diskriptif, maka dilakukan pembahasan untuk analisis faktor. Berikut ini adalah penjelasan dan langkahlangkah mengenai hasil pengolahan data dengan menggunakan analisis faktor.

a. Menentukan variabel yang akan dianalisa

Variabel yang akan dianalisis dalam penelitian ini adalah sejumlah 26 butir variabel yang telah lolos pada proses pengujian validitas dan reliabilitas sebelumnya. Untuk itu maka ke 26 variabel ini akan diuji dengan analisi faktor.

b. Menguji variabel-variabel yang telah ditentukan

Ke 26 variabel yang lolos uji validitas dan reliabilitas kemudian dimasukan dalam analisis faktor untuk di uji nilai KMO (Kaiser-Mayer-Olkin) dan Bartlett Test dan MSA (measures of sampling adequancy). Nilai yang harus diperoleh dalam KMO haruslah berada di atas 0,5 dan signifikan harus berada di bawah 0,05, sedangkan pada uji MSA nilai harus di atas 0,5 untuk dikatakan layak melakukan analisis faktor. Berikut adalah hasil yang diperoleh setelah melakukaun pengujian.

1) Keiser-Meyer-Olkin (KMO)

Tabel 13: KMO and Bartlett's Test

\begin{tabular}{|c|c|c|}
\hline \multicolumn{2}{|c|}{ Kaiser-Mey er-Olkin Measure of Sampling Adequacy. } & .867 \\
\hline \multirow[t]{3}{*}{ Bartlett's Test of Sphericity } & Approx. Chi-Square & $1.474 \mathrm{E} 3$ \\
\hline & Df & 325 \\
\hline & Sig. & .000 \\
\hline
\end{tabular}

Sumber: Hasil Output SPSS

Pada penelitian ini angka KMO dan Bartlett Test menunjukan 0,867 dengan tingkat signifikasi 0,000. Oleh karena hasil tersebut sudah di atas 0,5 dan signifikasi 
jauh dibawah $0,05(0,000<0,05)$, maka variabel dan selpel yang ada dapat dianalisis lebih lanjut.

\section{2) Anti-image Matrices}

Korelasi parsial antara antara varabel dinyatakan dalam angka-angka Anti-image Matrices yang merupakan korelasi yang tidak dipengaruhi variabel lain. Pada bagian ini angka-angka yang dilihat adalah angka yang membentuk garis diagonal yang memiliki tanda "a" yang menandakan nilai MSA sebuah variable pada tabel bagian Anti-image Corelation. Nilai MSA memiliki arti yang sama dengan KMO, hanya sifatnya saja yang berbeda yaitu pada MSA adalah parsial (setiap variabel/item/atribut)

Angka MSA pada peneletian ini menunjukan sebagai berikut: angka MSA variabel 1 adalah 0,865 , variabel 2 adalah 0,851 , variabel 5 adalah 0,912 , variabel 7 adalah 0,859 , variabel 8 adalah 0,728 , variabel 9 adalah 0,913 , variabel 10 adalah 0,902 , variabel 11 adalah 0,846 , variabel 12 adalah 0,866 , variabel 13 adalah 0,913 , variabel 14 adalah 0,905 , variabel 15 adalah 0,866 , variabel 16 adalah 0,799 , variabel 17 adalah 0,896 , variabel 19 adalah 0,845 , variabel 20 adalah 0,818 , variabel 21 adalah 0,837 , variabel 22 adalah 0,905 , variabel 23 adalah 0,871 , variabel 24 adalah 0,871 , variabel 25 adalah 0,910 , variabel 26 adalah 0,861 , variabel 29 adalah 0,881 , variabel 30 adalah 0,920 , variabel 31 adalah 0,889 , dan variabel 32 adalah 0,838 .

Dari ke 26 variabel yang ada, maka selanjutnya dapat dilihat nilai MSAnya. Apabila ada nilai MSA yang dibawah 0,5 maka variabel tersebut tidak dapat dianalisis lebih lanjut. Dari ke 26 variabel nilai MSA yang paling kecil adalah nilai yang dimiliki variabel 8 dengan nilai MSA 0,728 dan nilai MSA paling besar adalah nilai yang dimiliki variabel 30 dengan nilai MSA 0,920. Karena dari hasil pengujian tidak ada variabel yang mendapatkan nilai dibawah 0,5 maka selanjutnya dapat dilakukan analisis lebih lanjut.

c. Melakukan faktoring dan rotasi

Sesudah semua variabel memiliki nilai yang mencukupi, tahap selanjutnya adalah melakukan proses inti dari analisis faktor, yaitu melakukan ekstraksi terhadap sekumpulan variabel yang sudah ada, sehingga akan terbentuk satu atau lebih faktor. Dalam melakukan proses ekstraksi ini metode yang digunakan adalah Principal Component Analysis, setelah beberapa faktor terbentuk, dengan sebuah faktor yang berisi sejumlah variabel, jika ada variabel yang sulit ditentukan akan masuk faktor yang mana, maka akan dilakukan proses rotasi pada faktor yang terbentuk, sehingga akan memperjelas posisi sebuah variabel tadi, akankah masuk ke faktor satu atau faktor lainnya. Dalam penelitian ini proses rotasi menggunakan metode varimax ( bagian dari metode Orthogonal). 
Tabel 14: Communalities

\begin{tabular}{|l|r|r|}
\hline & Initial & Etraction \\
\hline Variabel1 & 1.000 & .639 \\
Variabel2 & 1.000 & .520 \\
Variabel5 & 1.000 & .555 \\
Variabel7 & 1.000 & .721 \\
Variabel8 & 1.000 & .709 \\
Variabel9 & 1.000 & .755 \\
Variabel10 & 1.000 & .609 \\
Variabel11 & 1.000 & .690 \\
Variabel12 & 1.000 & .756 \\
Variabel13 & 1.000 & .687 \\
Variabel14 & 1.000 & .587 \\
Variabel15 & 1.000 & .711 \\
Variabel16 & 1.000 & .635 \\
\hline Variabel17 & 1.000 & .422 \\
\hline
\end{tabular}

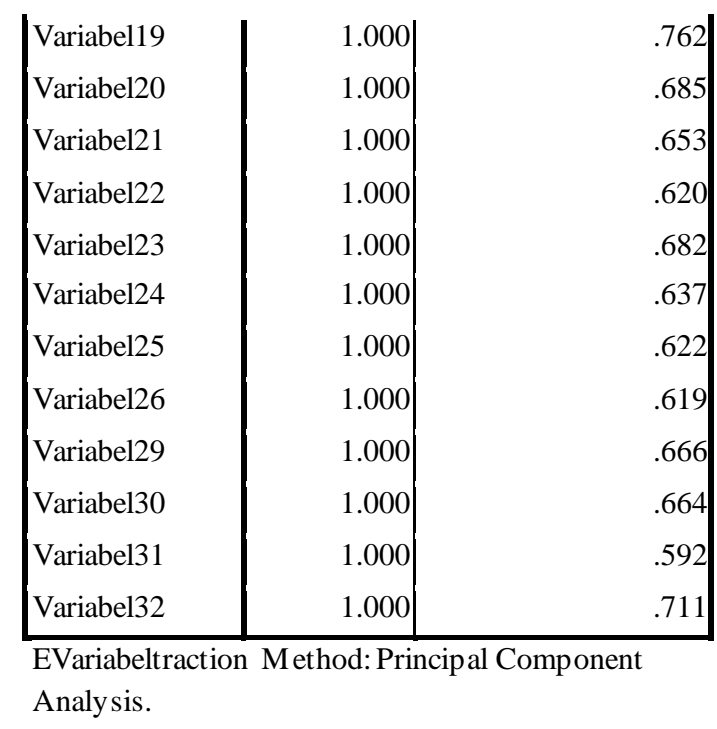

Sumber : Hasil Output SPSS

Tabel Communalities pada dasarnya adalah jumlah varians dalam presentase atau angka lainnya, suatu variabel mula-mula yang bisa dijelaskan oleh faktor yang ada. Sebagai contoh variabel 1 (terhindar dari riba) dengan angka 0,639 berarti 63,9\% varians dari variabel terhindar dari riba bisa dijelaskan oleh faktor yang terbentuk, demikian dengan variabel-variabel yang lainnya. Berdasarkan nilai-nilai yang ada pada tabel Communalities, maka dapat diambil kesimpulan bahwa variabel-variabel yang ada dapat dijelaskan didalam faktor terbentuk, semakin besar nilai communalities maka semakin erat hubungan faktor yang terbentuk.

Selanjutnya untuk mengetahui faktor yang terbentuk maka dapat dilihat dari tabel Total Variance Explained ( lampiran 1). Dalam melihat faktor terbentuk, maka harus dapat dilihat pada nilai Eigenvaluenya. Faktor terbentuk dapat diketahui jika nilai Eigenvaluenya di atas satu. Jika nilai eigenvalue lebih besar sama dengan satu maka faktor tersebut dianggap layak untuk dikatakan sebagai faktor yang terbentuk. Setiap faktor yang terbentuk mewakili variabel-variabel yang dianalisis, dengan kemampuan setiap faktor yang ditunjukan oleh besarnya varians yang dijelaskan dengan nilai eigenvalue.

Dari hasil penelitian menyatakan bahwa 26 variabel (component) yang dimasukan dalam analisis faktor membentuk lima faktor hal tersebut dapat dilihat bahwa terdapat lima faktor terbentuk yang nilai eigenvaluenya di atas angka satu, oleh sebab itulah hanya terbentuk 5 faktor.

Setelah diketahui bahwa lima faktor terbentuk. Maka tabel component matriks menunjukan distribusi ke 26 variabel tersebut pada lima faktor yang terbentuk. Sedangkan angka-angka yang ada pada tabel tersebut adalah factor loading, yang menunjukan besarnya korelasi suatu variabel dengan faktor 1 , faktor 2, faktor 3, faktor 4, atau faktor 5. Proses penentuan variabel mana yang akan masuk ke faktor mana, dilakukan dengan melakukan perbandingan besar korelasi pada setiap baris. Namun dalam Componen Matrik pendistribusian variabel belum bisa menentukan kemana variabel akan masuk faktor mana karena masih belum jelas dan nyata. Maka perlu dilakukan Rotated Component Matrix untuk memperlihatkan distribusi variabel yang lebih jelas dan nyata. 
Component matrix hasil proses rotasi (rotated component matrix) memperlihatkan distribusi variabel yang lebih jelas dan nyata. Terlihat bahwa seakrang faktor loading yang dulunya kecil semakin diperkecil, dan faktor loading yang besar semakin diperbesar. Pada rotated component matrix (Lampiran 3) variabel-variabel yang masuk pada tiap-tiap faktor adalah sebagai berikut: Faktor 1 terdiri dari: variabel-variabel Dengan menabung di BPRS Amanah Ummah nasabah dapat memenuhi kebutuhan dimasa yang akan datang (0.753), BPRS Amanah Ummah adalah Bank yang terkenal dan terpercaya (0.699), Staff BPRS Amanah Ummah menerapkan 6S (senyum, salam, sapa, sopan, santun, dan sabar) (0.645), Pelayanan yang cepat dari para staff BPRS Amanah Ummah (0.638), Pelayanan yang ramah dari para staff BPRS Amanah Ummah (0.592), Menabung di BPRS Amanah Ummah terhindar dari riba (0.584), Tujuan menabung adalah untuk mewujudkan impian nasabah (0.548), Dengan menabung di BPRS Amanah Ummah nasabah merasa aman (0.526). Faktor 2 terdiri dari: Syarat pembuatan rekening di BPRS Amanah Ummah mudah dan murah (0.782), BPRS Amanah Ummah menyediakan layanan jemput dana tabungan (0.682), Tabungan di BPRS Amanah Ummah menggunakan 2 jenis akad yaitu bagi hasil dan titipan (0.645), Nasabah BPRS Amanah Ummah dapat menabung sesuai kemampuan (0.614), BPRS Amanah Ummah menggunakan prinsip sayariah dalam setiap transiknya (0.598), Dengan menabung di BPRS Amanah Ummah nasabah merasa tenang (0.546). Faktor 3 terdiri dari: BPRS Amanah Ummah dekat dengan tempat tinggal atau tempat kerja (0.828), Lokasi BPRS Amanah Ummah yang strategis (0.696), Akses menuju BPRS Amanah Ummah sangat mudah (0.679), BPRS Amanah Ummah memiliki banyak kantor cabang dan kantor kas (0.546), BPRS Amanah Ummah menggunanakan media cetak dan media elektronik sebagai media promosinya (0.496). Faktor 4 terdiri dari: Sarana ruang tunggu di BPRS Amanah Ummah yang nyaman dan menyenang (0.764), Menabung di BPRS Amanah Ummah meningkatkan status sosial nasabah (0.752), Menabung di BPRS Amanah Ummah karena rekomendasi tempat kerja (0.715), Para pemimpin dan staff BPRS Amanah Ummah adalah orang yang amanah dan profesional (0.401). Faktor 5 terdiri dari: Menabung di BPRS Amanah Ummah memiliki fasilitas ATM yang memudahkan (0.647), Menabung di BPRS Amanah Ummah tidak ada potongan administrasi yang memberatkan (0.638), BPRS Amanah Ummah merupakan bank yang membantu masyarakat. (0.499).

\section{Component Transformation Matrix}

Tabel 15: Component Transformation Matrix

\begin{tabular}{|c|c|c|c|c|c|}
\hline Component & 1 & 2 & 3 & 4 & 5 \\
\hline 1 & .560 & .529 & .394 & .433 & .252 \\
\hline 2 & -.335 & -.118 & .875 & -.028 & -.327 \\
\hline 3 & .114 & -.723 & .004 & .675 & .097 \\
\hline 4 & -.741 & .374 & -.134 & .494 & .224 \\
\hline 5 & -.110 & -.211 & .247 & -.335 & .878 \\
\hline
\end{tabular}

Extraction Method: Principal Component Analysis.

Rotation Method: Varimax with Kaiser Normalization.

Sumber : Hasil Output SPSS

Pada tabel di atasa angka-angka yang terdapat pada arah diagonal ( dari kiri atas ke kanan bawah), yaitu component 1 dengan 1, sampai component 5 dengan 5 yaitu: faktor 1 adalah 0,560, faktor 2 adalah -0,118 (tanda “-” hanya menunjukan arah korelasi), faktor 3 adalah 0,004, faktor 4 
adalah 0,494, dan faktor 5 adalah 0,878. Walaupun hanya ada 2 faktor ( faktor 1 dan faktor 4) yang mempunyai nilai korelasi di atas 0,5 hal ini sudah cukup membuktikan ke 5 faktor tersebut sudah tepat. Meskipun lebih bagus lagi jika semua faktor mempunyai korelasi di atas 0,5 yang dapat membuktikan faktor yang tebentuk sangat tepat.

d. Interpretasi Atas Faktor Yang Telah Terbentuk

Setelah melakukan faktoring dan rotasi, langkah atau tahap selanjutnya adalah menginterpretasikan faktor yang terbentuk dengan pemberian nama dan konsep setiap faktor terbentuk berdasarkan makna umum variabel yang terdapat didalam faktor. Hal ini dilakukan agar bisa mewakili variabel-variabel anggota tersebut.

Faktor 1 yang terdiri dari: Dengan menabung di BPRS Amanah Ummah nasabah dapat memenuhi kebutuhan dimasa yang akan datang (0.753), BPRS Amanah Ummah adalah Bank yang terkenal dan terpercaya (0.699), Staff BPRS Amanah Ummah menerapkan 6S (senyum, salam, sapa, sopan, santun, dan sabar) (0.645), Pelayanan yang cepat dari para staff BPRS Amanah Ummah (0.638), Pelayanan yang ramah dari para staff BPRS Amanah Ummah (0.592), Menabung di BPRS Amanah Ummah terhindar dari riba (0.584), Tujuan menabung adalah untuk mewujudkan impian nasabah (0.548), Dengan menabung di BPRS Amanah Ummah nasabah merasa aman (0.526). Faktor ini dapat dinamakan dengan Faktor Pelayanan Prima ( Service Excellence).

Faktor pelayanan prima menjadi salah satu faktor yang mempengaruhi preferensi menabung nasabah di BPRS Amanah Ummah, yang terdiri dari variabel-variabel pembentuknya yang berhungungan dengan pelayanan prima. Sehingga dapat dikatakan pengaruh terbesar nasabah memilih menabung di BPRS Amanah Ummah disebabkan oleh pelayanan prima oleh bank. Pelayanan ini sangat penting untuk memperahankan dan menarik nasabah lebih banyak. Service Excellence adalah kepedulian kepada nasabah dengan memberikan layanan terbaik untuk memfasilitasi kemudahan, pemenuhan kebutuhan, dan mewujudkan kepuasannya agar nasabah selalu loyal kepada bank.

Bentuk pelayanan prima yang dilakukan oleh BPRS Amanah Ummah adalah seperti pelayanan yang cepat, pelayanan yang ramah, staff bank yang menerapkan $6 \mathrm{~S}$ ( Senyum, salam, sapa, sopan, santun, dan sabar), bank yang selalu menjaga amanah sehingga menjadi bank yang terpercaya, menghindari riba sebagai kewajiban nasabah muslim, memfasilitasi kemudahan nasabah dalam memenuhi kebutuhan dimasa yang akan datang dan impian nasabah, memberikan rasa aman kepada nasabah.

Faktor 2 terdiri dari: Syarat pembuatan rekening di BPRS Amanah Ummah mudah dan murah (0.782), BPRS Amanah Ummah menyediakan layanan jemput dana tabungan (0.682), Tabungan di BPRS Amanah Ummah menggunakan 2 jenis akad yaitu bagi hasil dan titipan (0.645), Nasabah BPRS Amanah Ummah dapat menabung sesuai kemampuan (0.614), BPRS Amanah Ummah menggunakan prinsip sayariah dalam setiap transiknya (0.598), Dengan menabung di BPRS Amanah Ummah nasabah merasa tenang (0.546). faktor ini dinamakan dengan Faktor keuntungan.

Keuntungan yang diberikan oleh pihak BPRS Amanah Ummah kepada nasabah adalah dengan memberikan nasabah biaya murah untuk pembuatan rekening, dan menggunakan pilihan 2 akad yaitu mudharabah nasabah memperoleh bagi hasil sesuai nisbah yang ditentukan perbulannya dan wadiah nasabah memperoleh bonus yang tidak ditentukan di awal. Selain itu keuntungan yang dapat diperoleh nasabah lainnya adalah nasabah dapat menabung sesuai kemampuan. Untuk 
nasabah yang bekerja sebagai pedagang yang ada di pasar, yaitu pasar leuwiliang, pasar jasinga, pasar anyar, pasar cigudeg, pasar jasinga, dsb, mereka diuntungkan dengan layanan jemput dana tabungan sehingga mereka tidak perlu meninggalkan pekerjaan dan harus menuju ke kantor BPRS Amanah Ummah untuk menabung. Faktor keuntungan sesuai dengan penelitian terdahulu yang dilalukan oleh Muhammad Darussalam pada tahun 2010, salah satu faktor yang dipentingkan oleh nasabah dalam memilih bank sebagai tempat menabung.

Faktor 3 terdiri dari: BPRS Amanah Ummah dekat dengan tempat tinggal atau tempat kerja (0.828), Lokasi BPRS Amanah Ummah yang strategis (0.696), Akses menuju BPRS Amanah Ummah sangat mudah (0.679), BPRS Amanah Ummah memiliki banyak kantor cabang dan kantor kas (0.546), BPRS Amanah Ummah menggunanakan media cetak dan media elektronik sebagai media promosinya (0.496). Faktor ini dinamakan faktor lokasi.

Dalam memilih sebuah bank sebagai tempat untuk menabung nasabah, faktor lokasi adalah faktor yang penting, dimana lokasi bank yang dekat dengan tempat tinggal atau tempat bekerja, lokasi yang strategis, dan akses menuju lokasi yang mudah merupakan hal yang mempengaruhi preferensi nasabah untuk menabung di sebuah bank. Selain itu lokasi promosi yang tepat juga menentukan dimana promosi baik menggunakan media cetak ataupun elektronik harus ditempat yang sesuai, ditempat yang mudah dilihat oleh masyarakat. BPRS Amanah Ummah merupakan bank yang berada di lokasi strategis, mudah diakses, dan dekat dengan pemukiman, pasar, dan perkantoran. Sesuai dengan karaktersitik nasabah yang menabung di BPRS Amanah Ummah adalah masyarkat yang memiliki tempat tinggal tidak jauh dari bank, ataupun masyarakat yang bekerja tidak jauh dari bank. Faktor lokasi juga sesuai dengan hasil penelitian yang dilakukan oleh Finna Putri Barna pada tahun 2010 yang menyatakan bahwa faktor lokasi adalah salah satu faktor yang mempengaruhi preferensi nasabah.

Faktor 4 terdiri dari: Sarana ruang tunggu di BPRS Amanah Ummah yang nyaman dan menyenang (0.764), Menabung di BPRS Amanah Ummah meningkatkan status sosial nasabah (0.752), Menabung di BPRS Amanah Ummah karena rekomendasi tempat kerja (0.715), Para pemimpin dan staff BPRS Amanah Ummah adalah orang yang amanah dan profesional (0.401). Faktor ini dinamakan faktor sosial dan kondisi bank.

Faktor sosial merupakan faktor yang mempengaruhi preferensi nasabah untuk menabung di BPRS Amanah Ummah, dari variabel menabung di BPRS Amanah Ummah karena rekomendasi tempat kerja, nasabah juga beranggapan menabung di BPRS Amanah Ummah meningkatkan status sosial, selain itu faktor yang mempengaruhi preferensi nasabah untuk menabung di BPRS Amanah Ummah adalah karena kelompok referensi, kelompok referensi adalah kelompok yang mempunyai pengaruh langsung maupun tidak langsung dalam hal ini adalah para pemimpin dan staff BPRS Amanah Ummah mereka memperkenalkan sikap dan konsep diri dan menciptakan tekanan kenyamanan yang mempengaruhi pilihan produk dari mereka sesuai dengan teori Kotler. Sedangkan suasana ruang tunggu yang nayaman dan menyenangkan menyadi atau kondisi bank menjadi faktor yang mempengaruhi preferensi nasabah untuk menabung di BPRS Amanah Ummah. Faktor sosial sesuai dengan penelitian yang dilakukan oleh Finna Putri Barna pada tahun 2010 dan Faktor kondisi bank sesuai dengan penelitian yang dilakukan oleh Muhammad Darussalam pada tahun 2010 tentang Analisis Faktor-faktor yang mempengaruhi preferensi nasabah bank syariah. 
Faktor 5 terdiri dari: Menabung di BPRS Amanah Ummah memiliki fasilitas ATM yang memudahkan (0.647), Menabung di BPRS Amanah Ummah tidak ada potongan administrasi yang memberatkan (0.638), BPRS Amanah Ummah merupakan bank yang membantu masyarakat. (0.499). Faktor ini dinamakan dengan faktor Fasilitas.

Fasilitas yang lengkap juga mempengaruhi seorang nasabah untuk memilih menabung di salah satu bank. Fasilitas yang diberikan oleh BPRS Amanah Ummah adalah dengan adanya ATM yang bekerja sama dengan bank syariah lainnya, selain itu dengan memberikan fasilitas tidak ada potongan administrasi yang memberatkan nasabah sehingga nasabah terbantu dengan fasilitas yang diberikan BPRS Amanah Ummah. Faktor fasilitas ini sesuai dengan penelitaian Finna Putri Barna pada tahun 2010 dimana dalam penelitiannya faktor produk dan fasilitas merupakan faktor yang mempengarhi preferensi nasabah terhadap bank syariah. Kemudian didukung dengan teori Philip Kotler bahwa salah satu bauran pemasaran yang mempengaruhi konsumen dalam menentukan pilihannya terhadap suatu produk atau jasa adalah fasilitas yang terdapat didalamnya.

Tentu saja penamaan pada faktor-faktor di atas belum pasti tepat, karena sulitnya melakukan generalisasi variabel yang ada. Namun demikian, sebuah faktor haruslah diberi nama yang sedapat mungkin mencerminkan isi faktor tersebut.

Menurut Ujianto Abdurrachman dalam penelitiannya untuk menentukan faktor-faktor yang paling dominan dengan melihat pada total nilai varians pada tebel Total Variance Explained (Lampiran 1). Berdasarkan hasil penelitian ini dan dari hasil analisis secara keseluruhan, ternyata faktor yang paling dominan mempengaruhi preferensi menabung nasabah di BPRS Amanah Ummah secara berurutan adalah faktor pelayanan prima (service excellence) dengan nilai varians $37,52 \%$, faktor keuntungan dengan nilai varians 8,92\%, faktor lokasi dengan nilai varians 7,62\%, faktor sosial dan kondisi bank dengan nilai varians $6,10 \%$, dan faktor fasilitas dengan nilai varians $4,88 \%$.

\section{Kesimpulan dan saran}

1. Faktor yang mempengaruhi preferensi menabung nasabah di BPRS Amanah Ummah dengan Analisis Faktor menunjukan bahwa ke-26 variabel direduksi menghasilkan 5 faktor, faktor-faktor yang terbentuk dari pembahasan di atas adalah:

a. Faktor 1 dinamakan faktor pelayanan prima (Service excellence) yang terdiri atas variabel: Dengan menabung di BPRS Amanah Ummah nasabah dapat memenuhi kebutuhan dimasa yang akan datang (0.753), BPRS Amanah Ummah adalah Bank yang terkenal dan terpercaya (0.699), Staff BPRS Amanah Ummah menerapkan 6S (senyum, salam, sapa, sopan, santun, dan sabar) (0.645), Pelayanan yang cepat dari para staff BPRS Amanah Ummah (0.638), Pelayanan yang ramah dari para staff BPRS Amanah Ummah (0.592), Menabung di BPRS Amanah Ummah terhindar dari riba (0.584), Tujuan menabung adalah untuk mewujudkan impian nasabah (0.548), Dengan menabung di BPRS Amanah Ummah nasabah merasa aman (0.526).

b. Faktor 2 dinamakan faktor keuntungan yang terdiri atas variabel: Syarat pembuatan rekening di BPRS Amanah Ummah mudah dan murah (0.782), BPRS Amanah Ummah menyediakan layanan jemput dana tabungan (0.682), Tabungan di BPRS Amanah Ummah menggunakan 2 jenis akad yaitu bagi hasil dan titipan (0.645), Nasabah BPRS Amanah Ummah dapat 
menabung sesuai kemampuan (0.614), BPRS Amanah Ummah menggunakan prinsip sayariah dalam setiap transiknya (0.598), Dengan menabung di BPRS Amanah Ummah nasabah merasa tenang (0.546).

c. Faktor 3 dinamakan faktor lokasi yang terdiri atas variabel: BPRS Amanah Ummah dekat dengan tempat tinggal atau tempat kerja (0.828), Lokasi BPRS Amanah Ummah yang strategis (0.696), Akses menuju BPRS Amanah Ummah sangat mudah (0.679), BPRS Amanah Ummah memiliki banyak kantor cabang dan kantor kas (0.546), BPRS Amanah Ummah menggunanakan media cetak dan media elektronik sebagai media promosinya (0.496).

d. Faktor 4 dinamakan faktor sosial dan kondisi bank yang terdiri atas variabel: Sarana ruang tunggu di BPRS Amanah Ummah yang nyaman dan menyenang (0.764), Menabung di BPRS Amanah Ummah meningkatkan status sosial nasabah (0.752), Menabung di BPRS Amanah Ummah karena rekomendasi tempat kerja (0.715), Para pemimpin dan staff BPRS Amanah Ummah adalah orang yang amanah dan profesional (0.401).

e. Faktor 5 dinamakan faktor fasilitas yang terdiri dari variabel: Menabung di BPRS Amanah Ummah memiliki fasilitas ATM yang memudahkan (0.647), Menabung di BPRS Amanah Ummah tidak ada potongan administrasi yang memberatkan (0.638), BPRS Amanah Ummah merupakan bank yang membantu masyarakat. (0.499).

2. Faktor yang paling dominan dalam mempengaruhi preferensi menabung nasabah di BPRS Amanah Ummah adalah faktor pelayanan prima (service excellence) dengan nilai varians $37,52 \%$. Faktor ini menjadi faktor yang dominan karena memiliki nilai varians paling tinggi dibandingkan dengan faktor lainnya pada tabel total variance explaind. Itu berarti menunjukan sebanyak 37,52\% nasabah memilih menabung di BPRS Amanah Ummah karena faktor pelayanan prima dari bank, nasabah beranggapan bahwa bank telah memberikan pelayanan terbaik untuk memfasilitasi kemudahan, pemenuhan kebutuhan dan mewujudkan kepuasan nasabah meliputi, bank dapat memenuhi kebutuhan dimasa yang akan datang, bank yang terkenal dan terpercaya, staff yang menerapkan $6 \mathrm{~S}$ ( senyum, salam, sapa, sopan, santun, dan sabar), staff yang ramah, pelayanan yang cepat, terhindar dari riba, mewujudkan impian nasabah, dan membuat rasa aman nasabah.

\section{Referensi}

BPRS Amanah Ummah. (2016). Laporan Tahunan 2016 BPRS Amanah Ummah. PT. BPRS Amanah Ummah: Bogor.

Darussalam, M. (2010). "Analisis Faktor-faktor yang dipentingkan nasabah tabungan bank pembiayan rakyat syariah Amanah Ummah Leuwiliang”. IPB: Bogor.

Fitri, M. (2016). "Peran Dana Pihak Ketiga Dalam Kinerja Lembaga Pembiayaan Syariah Dan Faktor-faktor Yang Memengaruhinya”. Jurnal Economica, Vol. VII, edisi 1,Mei.

Hilman ,I., et al. (2003). Perbankan Syariah Masa Depan. Senayan Abadi Publishing: Jakarta.

$\mathrm{Http} / / / \mathrm{www}$. amanahummah.co.id/index.php?option=com_content\&view=article\&id=129\&Itemid= 108 (di akses 03 Agustus 2017)

Ismail. (2011). Perbankan Syariah. Kencana: Jakarta.

Jaya, H., K. (2016). "Analisis Faktor-Faktor Yang Mempengaruhi Preferensi Konsumen Dalam Keputusan Pembelian Teh Celup Sariwangi Studi Kasus Masyarakat Kota Bekasi”. UIN Jakarta: Jakarta 
J. Setiadi, N. (2003). Perilaku Konsumen Konsep Dan Implikasi Untuk Strategi Dan Penelitian Pemasaran. Kencana: Jakarta.

Kasmir. (2003). Dasar - Dasar Perbankan. Rajawali Pers: Jakarta.

Kotler, P., \& Keller, K., L. Manajeman Pemasaran.edisi ke-13, jilid 1. Erlangga: Jakarta.

Lovelock dan wirtz (Http://www.syariahfinance.com/opini/375-pelayanan-bank -syariah.html) (diakses 30 September 2017)

Machfoedz, M. (2010). Komuikasi Pemasaran Modern. Cakra Ilmu: Jakarta.

Naf'an, Pembiayaan Musyarakah dan Mudharabah, Yogyakarta : Graha Ilmu, 2014.

Otoritas Jasa Keuangan, Statistik Perbankan Syariah, Mei 2017 http $/ /$ www.ojk.go.id/id/kanal/syariah/data-dan-statistik/statistik-perbankansyariah/Pages/Statistik-Perbankan-Syariah---Mei-2017.aspx

Putri, F., B. (2010). "Analisis Faktor-Faktor yang mempengaruhi Preferensi Nasabah Bank Syariah (Studi Kasus Pada Bank Mega Syariah KCP Panglima Poman)”, Uin Syarif Hidayatullah: Jakarta.

Rianto, M., N. (2012). Dasar- dasar pemasaran Bank Syariah. Alfabeta: Bandung.

Rianto, M., N, \& Euis A. (2014). Teori Mikroekonomi ( Suatu Perbandingan Ekonomi Islam dan Ekonomi Konvensional. Kencana: Jakarta.

Rianto, M., N. (2012). Lembaga Keuangan Syariah Suatu Teoritis Praktis. Pustaka Setia: Bandung.

Simamora, B. (2004). Panduan Riset Perilaku Konsumen. PT Gramedia Pustaka: Jakarta.

Sugiono. (2007). Metode penelitian Administrasi. Alfabeta: Bandung.

Supranto, J., dan Nandan, L. (2007). Perilaku Konsumen Dan Strategi Pemasaran Untuk Memenangkan Persaingan Bisnis. Wacana Media: Jakarta.

Suryani dan Hendryadi. (2015). Metode Riset Kuantitatif Teori Dan Aplikasi Pada Penelitian Bidang Manajemen Dan Ekonomi Islam. Kencana: Jakarta.

Sofyan, I. (2016). "Analisis persepsi, perilaku, dan preferensi masyarakat santri terhadap perbankan syariah (pondok pesantren modern ibadurrahman”). UIN Syarif Hidayatullah: Jakarta.

Ujianto, A. (2004). "Analisis Faktor-Faktor yang Menimbulkan Kecenderungan Minat Beli Konsumen Sarung (Studi Perilaku Konsumen Sarung di Jawa Timur)”, Jurnal Manajemen \& Kewirausahaan Vol. 6, No. 1, Maret.

Umar, H. (2000). Riset pemasaran dan perilaku konsumen. Gramedia Pustaka Utama: Jakarta.

Yamin, S., \& Heri, K. (2009). SPSS Complete Teknik Analisis Statistik Terlengkap Dengan Software SPSS. Salemba Infotek: Jakarta.

Zuhri, M. (1996). Riba dalam Alqur'an dan Masalah Perbankan (Sebuah Telitik Antisipatif). Rajawali Pers: Jakarta. 